\title{
UJI PERFORMA WRF DENGAN DATA ASIMILASI RADAR, SATELIT DAN SYNOP UNTUK PREDIKSI HUJAN DI JAKARTA
}

\author{
WRF Performance Test with Assimilation Radar, Satellite and Synop Data \\ for Rainfall Prediction in Jakarta
}

\author{
Ardi Widi Lestanto' ${ }^{1}$, Jaka Ivanda Anugrah Paski²) \\ 1) Sekolah Tinggi Meteorologi Klimatologi dan Geofisika. Jl. Perhubungan 1 No. 5 \\ Pondok Betung, Tangerang Selatan \\ 2) Badan Meteorologi Klimatologi dan Geofisika. Jl. Angkasa I No.2 Kemayoran \\ Jakarta Pusat 10720 Indonesia \\ *E-mail: ardiwidilestanto@gmail.com
}

\begin{abstract}
Intisari
Asimilasi data merupakan suatu metode estimasi yang diperoleh dari penggabungan antara output model NWP dan data-data pengukuran. Dalam beberapa tahun terakhir, model mesoscale resolusi tinggi diinisialisasi dengan menggunakan teknik data asimilasi (3DVAR/4DVAR) yang diterapkan untuk mempelajari fenomena meteorologi. Penelitian ini dilakukan di wilayah Jakarta dengan memanfaatkan data observasi sinoptik, data radiance satelit dan data radar Doppler C-Band EEC (Enterprise Electronics Corporation) di Jakarta. Penelitian ini menggunakan model numerik Weather Research and Forecasting (WRF) untuk menjalankan model tanpa asimilasi dan model dengan asimilasi data radar, satelit dan sinoptik menggunakan sistem 3DVAR. Analisis dilakukan secara kuantitatif untuk menguji performa model terhadap data observasi dan analisis spasial dengan mencari nilai selisih curah hujan dengan data GSMaP melalui metode overlay. Hasil membuktikan performa terbaik dari hasil prediksi distribusi hujan spasial adalah model asimilasi satelit kemudian model asimilasi radar dan terakhir model asimilasi synoptic. Uji performa melalui tabel kontingensi untuk mengetahui nilai PC, TS, FAR, dan POD. Model asimilasi satelit memiliki performa paling baik daripada model asimilasi lain. Untuk prediksi sesuai kategori hujan ringan model asimilasi satelit yang terbaik, sementara untuk kategori hujan sangat lebat model asimilasi synop adalah yang paling unggul.
\end{abstract}

Kata Kunci : WRF, Asimilasi Data, Radar Cuaca, Satelit Radiasi, Sinoptik.

\begin{abstract}
Data assimilation is an estimation method that is built by merging outputs from NWP model and those from measurement activities. In the last few years, high resolution mesoscale model, initialized with (3DVAR/4DVAR) assimilation data, had been applied to study meteorological phenomenon. This research was conducted in the Jakarta region by using Jakarta-based synoptic observation, radiance satellite and Doppler C-Band EEC radar data. This research uses Weather Research and Forecasting numerical model to run non-assimilation model and assimilated radar data, satellite and synoptic-based model which utilizes 3DVAR system. Quantitave analysis was conducted to test the model performance with respect to the observation data and spatial analysis was also conducted to determine differences in rainfall value with GSMap data through the overlay method. The results proves that the best-performing spatial rainfall distribution prediction is first the satellite assimilation model, followed by the radar assimilation model, and the last one being the synoptic assimilation model. The performance test uses contingency table to determine PC, TS, FAR and POD values. It was also found that Satellite assimilation based-model have better performance compared to other assimilation models. For slight rain category-based prediction, satellite assimilation based-model was found to be the best while for heavy rain category, synoptic assimilation based-model was to be the most superior.
\end{abstract}

Keywords : WRF, Data Assimilation, Weather Radar, Radiance Satellite, Synoptic.

\section{PENDAHULUAN}

Prediksi cuaca numerik adalah suatu model cuaca numerik yang dianggap dapat merepresentasikan keadaan alam yang sebenarnya untuk membantu agar informasi cuaca dapat diperoleh dengan cepat dan tepat, salah satunya menggunakan model cuaca Weather Research Forecasting (WRF). Namun perlu adanya kajian lebih lanjut untuk 
meningkatkan akurasi prediksi keluaran model WRF. Keakuratan data hasil prediksi tidak hanya bergantung pada resolusi yang digunakan, akan tetapi juga bergantung pada kondisi awal yang digunakan dalam integrasi model tersebut. Selain masalah menentukan kombinasi skema yang cocok pada daerah tersebut, faktor kondisi awal juga harus diperhatikan dalam prediksi cuaca numerik saat ini.

Penelitian dan pengembangan tentang suatu pendekatan yang memakai data asli hasil pengamatan sebagai keadaaan awal, pendekatan ini disebut asimilasi data (Data Assimiliation DA), yang tujuannya didefinisikan oleh Talagrand (1997) sebagai "menggunakan semua informasi yang tersedia, untuk menentukan keadaan aliran atmosfer (atau lautan) seakurat mungkin" (Kalnay, 2003). Model harus menghitung efek agregat dari permukaan yang mempengaruhi aliran level bawah dengan sebuah single number yang dapat sejalan dengan bentuk gaya gesek di persamaan prediksi angin, sehingga diperlukan parameterisasi untuk menghitung efek-efek tersebut tanpa secara langsung memprediksinya (Hadi et al., 2011).

Asimilasi data merupakan suatu metode estimasi yang diperoleh dari penggabungan antara output model NWP dan data-data pengukuran. Dalam beberapa tahun terakhir, model mesoscale resolusi tinggi diinisialisasi dengan menggunakan teknik data asimilasi (3DVAR/4DVAR) yang diterapkan untuk mempelajari fenomena meteorologi (Kalnay, 2003).

Data yang bisa digunakan sebagai data asimilasi adalah data observasi (sinop, metar, rason, dll) dan data observasi radiasi satelit, sedangkan data radar yang digunakan adalah data reflectivity dan radial velocity (Sun \& Wang, 2013; Paski, 2017). Data satelit sangat penting karena merupakan sumber informasi observasi utama terbesar untuk prediksi cuaca numerik global dan mempunyai dampak positif pada model dengan area terbatas (Auligne et al., 2009). Data radiance yang akan digunakan adalah data radiance AMSU-A dan MHS (Yang et al., 2015) dan data radar yang digunakan hanya data reflektivitas dengan teknik sampling nilai reflektivitas terbesar (Satrya, 2012).

Penelitian ini dilakukan di wilayah Jakarta memanfaatan data observasi sinoptik, data radiance satelit dan data radar Doppler C-Band EEC (Enterprise Electronics Corporation) di Jakarta dengan menambahkan data observasi asli pada syarat awal model WRF menggunakan metode asimilasi data untuk mengetahui performa prediksi cuaca terutama prediksi hujan pada wilayah penelitian dengan menggunakan teknik asimilasi 3DVAR. Seperti pada penelitian serupa sebelumnya yang menggunakan teknik asimilasi 3DVAR dan menghasilkan perbaikan pada prediksi parameter meteorologi (Dash et al., 2013; Sahu et al., 2014).
Dalam penelitian ini akan diteliti bagaimana hasil pengujian performa WRF dengan menggunakan data asimilasi berupa data observasi sinoptik, data radiance satelit cuaca dan data radar cuaca. Terdapat 11 hari kejadian yang dibagi menjadi 3 hari pada musim kemarau, 3 hari pada musim hujan, 3 hari pada musim peralihan kemarau ke hujan dan 2 hari pada musim peralihan hujan ke kemarau di wilayah Jakarta dengan parameterisasi yang sudah ditentukan. Selanjutnya penelitian ini juga akan terfokus pada bagaimana hasil prediksi asimilasi jika dibandingkan terhadap data hasil observasi hujan di wilayah Jakarta. Pengambilan lokasi Jakarta didasarkan karena topgrafinya yang sangat memungkinkan terjadinya pertumbuhan awan konvektif penyebab cuaca buruk (Paski, 2016).

Penelitian ini bertujuan untuk mendownscale data GFS dengan menggunakan WRFDA untuk melihat seberapa jauh tingkat akurasi dari hasil keluaran model WRF dengan asimilasi data yang masing-masing menggunakan data observasi, data radiasi satelit dan data radar dengan data pengamatan sebenarnya di beberapa pos pengamatan hujan BMKG di wilayah dengan mempertimbangkan skema yang digunakan adalah skema parameterisasi yang stabil untuk daerah Jakarta (Paski, 2017).

\section{METODE}

\subsection{Data dan Lokasi}

Data observasi curah hujan menggunakan data pada tanggal 24 Januari, 25 dan 26 Februari, 20 April, 20 dan 21 Mei, 11, 22 dan 23 Agustus, serta 23 dan 25 Oktober tahun 2016 yang diambil dari beberapa pos pengamatan hujan BMKG yang berada di provinsi DKI Jakarta. Data yang digunakan dalam model WRF asimilasi dan tanpa asimilasi menggunakan data observasi permukaan maupun penginderaan jauh (radar dan satelit) dengan menggunakan teknik 3DVAR meliputi data:

a) Data GFS dengan resolusi $0.25^{\circ} \times 0.25^{\circ}$ sampai dengan 36 jam ke depan, dengan 12 jam pertama pada hari sebelumnya sebagai waktu spin up pada musim penghujan, musim peralihan hujan ke kemarau, musim kemarau dan musim peralihan hujan ke kemarau diunduh dari http://rda.ucar.edu.

b) Data C-Band Doppler Radar (CDR) BMKG Tangerang tanggal pukul 00.00 UTC digunakan sebagai data observasi untuk inisial prediksi numerik, yang diperoleh dari sub-bid radar BMKG,

c) Data curah hujan GSMaP NRT dengan resolusi $0.25^{\circ} \times 0.25^{\circ}$, yang diperoleh dari subbid satelit BMKG.

d) Data Observasi meteorologi dalam format LITTLE_R, yang diunduh dari http://rda.ucar.edu. 
e) Data Radiance satelit AMSU-A dan MHS dalam format BUFR, yang diunduh dari http://rda.ucar.edu.

f) Data Background Error (BE) yang didapat dari modul WRFDA untuk mendapatkan data inisial tambahan yang diperlukan. Dalam hal ini menggunakan data BE cv7.

\subsection{Metode Penelitian}

Dalam penelitian ini digunakan model WRFDA untuk proses asimilasi seperti yang telah dilakukan oleh Paski (2017). Domain model WRF pada penelitian ini dikonfigurasi menjadi 3 domain dengan skema downscalling, sehingga diharapkan akurasi prediksi semakin baik. Domain terkecil memiliki resolusi hingga $3 \mathrm{~km}$ yang mencakup wilayah Jakarta (Gambar 1).

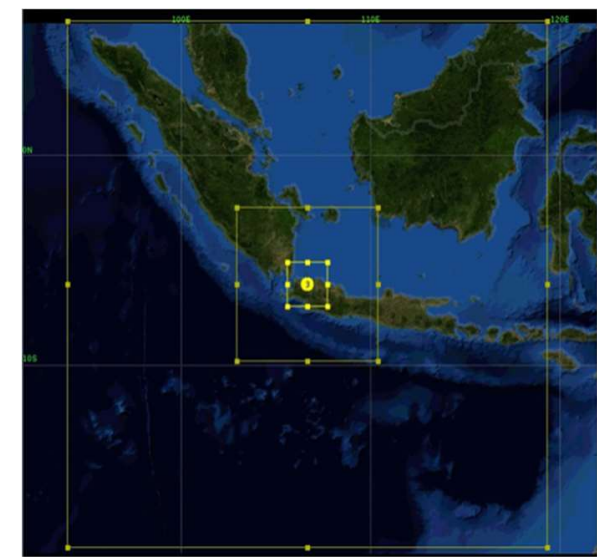

Gambar 1. Domain penelitian model WRF.

Parameterisasi model menggunakan konfigurasi yang telah diteliti untuk wilayah Jakarta oleh Gustari (2014) yang kemudian juga diterapkan pada penelitian Paski (2017). Konfigurasi model WRF yang digunakan seperti yang ditampilkan pada Tabel 1.

Tabel 1. Konfigurasi Parameterisasi Model WRF.

\begin{tabular}{|c|c|c|c|}
\hline Konfigurasi & $\begin{array}{l}\text { Domai } \\
\text { n } 1\end{array}$ & $\begin{array}{l}\text { Domai } \\
\text { n } 2\end{array}$ & $\begin{array}{l}\text { Domai } \\
\text { n } 3\end{array}$ \\
\hline $\begin{array}{l}\text { Resolusi grid } \\
\text { Horizontal }\end{array}$ & $27 \mathrm{Km}$ & $9 \mathrm{Km}$ & $3 \mathrm{Km}$ \\
\hline $\begin{array}{l}\text { Skema } \\
\text { Mikrofisika }\end{array}$ & \multicolumn{3}{|c|}{ Purdue - Lin } \\
\hline $\begin{array}{c}\text { Skema } \\
\text { Parameterisas } \\
\text { i Cumulus }\end{array}$ & \multicolumn{3}{|c|}{ Kain - Fritsch } \\
\hline Skema PBL & \multicolumn{3}{|c|}{ YSU } \\
\hline $\begin{array}{l}\text { Resolusi } \\
\text { Temporal }\end{array}$ & \multicolumn{3}{|c|}{180} \\
\hline $\begin{array}{c}\text { Jumlah Level } \\
\text { Vertikal }\end{array}$ & \multicolumn{3}{|c|}{30 Lapisan } \\
\hline
\end{tabular}

Dalam menjalankan model WRF dengan asimilasi pada WRFDA untuk 3DVAR diperlukan beberapa data asimilasi yang dapat dilihat pada Tabel 2. Proses yang dipersiapkan berbeda dengan menjalankan model tanpa asimilasi, terutama pada namelist dan post processing. Data yang dihasilkan memiliki format yang sama yaitu .ctl dan .dat. Skema yang dijalankan disesuaikan dengan konfigurasi namelist.input pada WRF. Dalam penelitian ini akan didapatkan tiga model prediksi dengan teknik asimilasi yaitu asimilasi synop, asimilasi radar dan asimilasi satelit, serta satu model tanpa asimilasi.

Tabel 2. Data Inisiasi Model WRFDA untuk Teknik 3D-Var.

\begin{tabular}{ccc} 
Input data & Format & Proses \\
\hline Prediksi awal & NetCDF & $\begin{array}{c}\text { WPS dan } \\
\text { real.exe }\end{array}$ \\
\hline Radar & $\begin{array}{c}\text { ASCII } \\
\text { (PREBUFR } \\
\text { juga bisa) }\end{array}$ & OBSPROC \\
\hline $\begin{array}{c}\text { Observasi } \\
\text { meteorologi }\end{array}$ & ASCI & OBSPROC \\
\hline $\begin{array}{c}\text { Radiance } \\
\text { satelit }\end{array}$ & BUFR & - \\
\hline $\begin{array}{c}\text { Stastistik BE } \\
\text { Bunary }\end{array}$ & Binary & $\begin{array}{c}\text { WRFDA } \\
\text { gen_be }\end{array}$
\end{tabular}

Tabel 3. Tabel Kontingensi.

\begin{tabular}{|c|c|c|c|}
\hline & \multicolumn{2}{|c|}{ Observation } \\
\hline & & YES & NO \\
\hline \multirow{2}{*}{ 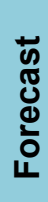 } & $\underset{\sim}{\stackrel{\sim}{二}}$ & Hits & False Alarm \\
\hline & $\stackrel{\circ}{Z}$ & Misses & Correct Negatives \\
\hline
\end{tabular}

Tabel kontingensi digunakan untuk menganalisis kejadian hujan yang merupakan data diskrit dan diolah secara statistik. Untuk melakukan analisis terhadap tabel kontingensi pada Tabel 3 dapat menggunakan nilai-nilai seperti Percent Correct (PC), Treat Score (TS), Probability of Detection (POD) dan False Alarm Ratio (FAR) dari tabel kontingensi.

Percent Correct (PC) digunakan untuk menjawab secara keseluruhan berapa besar forecast yang bernilai benar. Threat Score (TS) digunakan untuk melihat seberapa baik model memprediksi hujan. Probability of Detection (POD) digunakan untuk mengukur banyaknya hujan observasi yang dapat diprakirakan dengan benar. False Alarm Ratio (FAR) digunakan untuk mengukur banyaknya hasil forecast yang tidak benar-benar terjadi. Dengan nilai 1 untuk sempurna pada PC, TS dan POD, sedangkan nilai 0 sempurna untuk FAR. 
- $\quad P C=\frac{\text { Hits }+ \text { Correct Negatives }}{\text { Total }}$

- $\quad P O D=\frac{\text { Hits }}{\text { Hits }+ \text { Misses }}$

- $\quad F A R=\frac{\text { False Alarms }}{\text { Hits }+ \text { False Alarms }}$

- $T S=\frac{\text { Hits }}{\text { Hits }+ \text { False Alarms }+ \text { Misses }}$

\section{HASIL DAN PEMBAHASAN}

Pada penelitian ini, hasil keluaran model WRF dengan asimilasi maupun non asimilasi ditampilkan menggunakan GrADS kemudian hasil olahan dianalisis secara spasial dengan mencari nilai bias antara hasil model prediksi dibandingkan dengan nilai observasi satelit GSMaP. Selain itu hasil prediksi tersebut diverifikasi dengan data observasi 23 titik pos pengamatan hujan BMKG menggunakan beberapa metode statistik. Data curah hujan yang akan digunakan adalah akumulasi 24 jam dengan sampel 11 hari kemudian di analisis untuk menampilkan nilai Percent Correct (PC), Probability of Detection
(POD), False Alarm Ratio (FAR) dan Threat Score (TS).

\subsection{Verifikasi Hujan Keseluruhan}

Hasil verifikasi prakiraan dikotomi (ya/tidak hujan) ditampilkan pada Tabel 4 dan 5 . Berdasarkan parameter akurasi yang digunakan, untuk hasil model dengan asimilasi satelit menunjukkan nilai akurasi (PC) sebesar 0.81, nilai kemampuan mendeteksi kejadian hujan (POD) sebesar 0.87 , artinya 87 persen dari hujan yang terjadi adalah dapat diprediksi.

Hasil model tanpa asimilasi data mempunyai nilai akurasi parameter terendah di antara keempat model. Nilai akurasi (PC) sebesar 0.74 dan POD sebesar 0.75 , namun perbandingan kejadian yang tidak terdeteksi terhadap total prediksi kejadian (FAR) sebesar 0.08 . Model dengan asimilasi sinoptik dan model dengan asimilasi data radar memiliki hasil yang hampir berimbang, tercatat memiliki nilai akurasi sebesar 0.78 dan 0.77 .

Berdasarkan parameter diatas, secara umum model dengan asimilasi data satelit yang paling baik.

Tabel 4. Hasil Verifikasi Secara Dikotomi Menggunakan Tabel Kontingensi di Jakarta.

Model Hits False Alarm Misses Correct Negative

\begin{tabular}{lcccc}
\hline Tanpa Asimilasi & 156 & 14 & 51 & 32 \\
\hline Asimilasi Synop & 169 & 19 & 37 & 28 \\
\hline Asimilasi Radar & 164 & 17 & 42 & 30 \\
\hline Asimilasi Satelit & 181 & 21 & 26 & 25
\end{tabular}

Tabel 5. Hasil Nilai Indeks Analisis Performa Model di Jakarta.

\begin{tabular}{ccccc} 
Model & PC & POD & FAR & TS \\
\hline Tanpa Asimilasi & 0.74 & 0.75 & 0.08 & 0.71 \\
\hline Asimilasi Synop & 0.78 & 0.82 & 0.10 & 0.75 \\
\hline Asimilasi Radar & 0.77 & 0.80 & 0.09 & 0.74 \\
\hline Asimilasi Satelit & 0.81 & 0.87 & 0.10 & 0.79
\end{tabular}




\subsection{Verifikasi Hujan Menurut Kriteria}

Pada kasus hujan intensitas ringan yang terjadi selama 11 hari sampel yang diangkat pada penelitian ini ada 97 kasus hujan intensitas ringan. Kejadian ditentukan dari data curah hujan pada pos hujan, dimana data tersebut digolongkan kedalam intensitasnya. Model dengan asimilasi data keseluruhan lebih unggul dalam memprediksi hujan intensitas ringan dibanding dengan model tanpa asimilasi. Model dengan asimilasi data satelit yang paling unggul diantara model dengan asimilasi data sinoptik dan asimilasi data radar dengan persentase hit 0.80 (Tabel 6).

Tabel 6. Persentase Performa Prediksi Hujan Ringan dengan Model di Jakarta.

\begin{tabular}{cccc} 
Model & $\begin{array}{c}\text { Under } \\
\text { estimated }\end{array}$ & HIT & $\begin{array}{c}\text { Over } \\
\text { estimated }\end{array}$ \\
\hline $\begin{array}{c}\text { Tanpa } \\
\text { Asimilasi }\end{array}$ & 0.31 & 0.64 & 0.05 \\
\hline $\begin{array}{c}\text { Asimilasi } \\
\text { Synop }\end{array}$ & 0.24 & 0.74 & 0.02 \\
\hline $\begin{array}{c}\text { Asimilasi } \\
\text { Radar }\end{array}$ & 0.19 & 0.73 & 0.08 \\
\hline $\begin{array}{c}\text { Asimilasi } \\
\text { Satelit }\end{array}$ & 0.15 & 0.80 & 0.04
\end{tabular}

Tabel 7. Persentase Performa Prediksi Hujan Sedang dengan Model di Jakarta.

\begin{tabular}{cccc} 
Model & $\begin{array}{c}\text { Under } \\
\text { estimated }\end{array}$ & HIT & $\begin{array}{c}\text { Over } \\
\text { estimated }\end{array}$ \\
\hline $\begin{array}{c}\text { Tanpa } \\
\text { Asimilasi }\end{array}$ & 0.71 & 0.23 & 0.06 \\
\hline $\begin{array}{c}\text { Asimilasi } \\
\text { Synop }\end{array}$ & 0.76 & 0.18 & 0.06 \\
\hline $\begin{array}{c}\text { Asimilasi } \\
\text { Radar }\end{array}$ & 0.76 & 0.23 & 0.02 \\
\hline $\begin{array}{c}\text { Asimilasi } \\
\text { Satelit }\end{array}$ & 0.76 & 0.21 & 0.03
\end{tabular}

Kejadian hujan intensitas sedang yang terjadi selama 11 hari sampel yang diangkat pada penelitian ini terdapat 62 kasus. Model secara keseluruhan menunjukkan nilai curah hujan yang cenderung underestimate dibanding dengan data observasi pos hujan. Model dengan asimilasi radar dan tanpa asimilasi memprediksi 23\% kemudian model dengan asimilasi satelit $21 \%$ dan model dengan asimilasi sinoptik $18 \%$ dari kasus hujan intensitas sedang yang terjadi (Tabel 7 ).

Kejadian hujan intensitas lebat yang terjadi selama 11 hari sampel yang diangkat pada penelitian ini terdapat 27 kasus. Seluruh model diatas $80 \%$ menunjukkan hasil yang underestimate dibanding dengan hasil pengamatan pada pos hujan. Model dengan asimilasi satelit memiliki nilai hit $0 \%$ sedangkan tertinggi adalah model dengan asimilasi sinoptik dan tanpa asimilasi mampu memprediksi 15\% (Tabel 8).

Tabel 8. Persentase Performa Prediksi Hujan Lebat dengan Model di Jakarta.

\begin{tabular}{cccc} 
Model & $\begin{array}{c}\text { Under } \\
\text { estimated }\end{array}$ & HIT & $\begin{array}{c}\text { Over } \\
\text { estimated }\end{array}$ \\
$\begin{array}{c}\text { Tanpa } \\
\text { Asimilasi }\end{array}$ & 0.85 & 0.15 & 0.00 \\
\hline $\begin{array}{c}\text { Asimilasi } \\
\text { Synop }\end{array}$ & 0.81 & 0.15 & 0.04 \\
\hline $\begin{array}{c}\text { Asimilasi } \\
\text { Radar }\end{array}$ & 0.93 & 0.04 & 0.04 \\
\hline $\begin{array}{c}\text { Asimilasi } \\
\text { Satelit }\end{array}$ & 1.00 & 0.00 & 0.00 \\
\hline
\end{tabular}

Tabel 9. Persentase Performa Prediksi Hujan Sangat Lebat dengan Model di Jakarta.

\begin{tabular}{cccc} 
Model & $\begin{array}{c}\text { Under } \\
\text { estimated }\end{array}$ & HIT & $\begin{array}{c}\text { Over } \\
\text { estimated }\end{array}$ \\
\hline $\begin{array}{c}\text { Tanpa } \\
\text { Asimilasi }\end{array}$ & 0.78 & 0.22 & 0.00 \\
\hline $\begin{array}{c}\text { Asimilasi } \\
\text { Synop }\end{array}$ & 0.50 & 0.50 & 0.00 \\
\hline $\begin{array}{c}\text { Asimilasi } \\
\text { Radar }\end{array}$ & 0.89 & 0.11 & 0.00 \\
\hline $\begin{array}{c}\text { Asimilasi } \\
\text { Satelit }\end{array}$ & 1.00 & 0.00 & 0.00
\end{tabular}

Kejadian hujan intensitas sangat lebat yang terjadi selama 11 hari sampel yang diangkat pada penelitian ini terdapat 18 kasus. Model dengan asimilasi sinoptik muncul sebagai model terbaik dengan persentase $50 \%$ sedangkan sama seperti kasus hujan intensitas lebat model dengan asimilasi satelit hasilnya seluruhnya adalah underestimate (Tabel 9). Secara keseluruhan dapat diketahui bahwa model dengan asimilasi data sangat baik jika diterapkan untuk memprediksi hujan intensitas ringan ataupun secara dikotomi, sementara untuk digunakan memprediksi hujan sedang, lebat dan sangat lebat performanya akan jauh menurun, kecuali kasus 
hujan intensitas sangat lebat menggunakan asimilasi data sinoptik.

\subsection{Verifikasi Spasial}
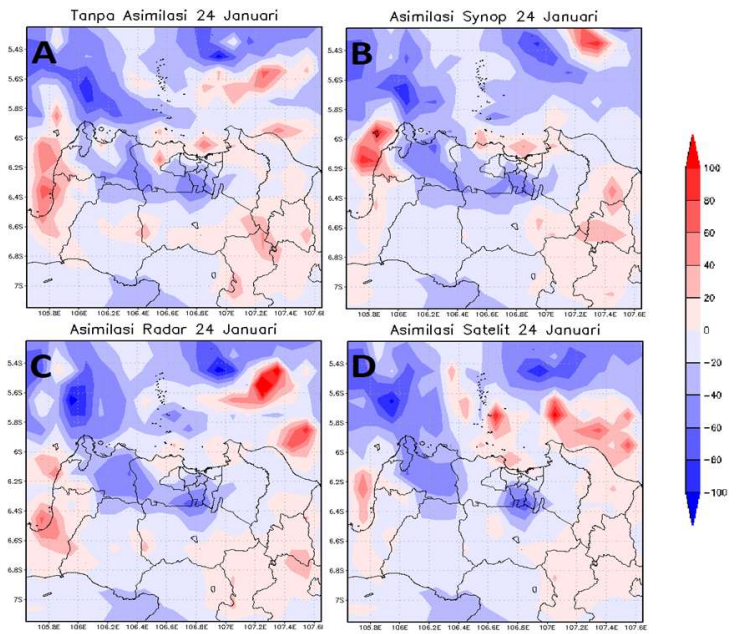

Gambar 2. Selisih curah hujan spasial GSMaP dan model numerik wilayah Jakarta hasil overlay tanggal 24 januari 2016.

Hasil distribusi selisih curah hujan antara model prediksi dengan data satelit GSMaP pada Gambar 2 menunjukkan hasil keluaran model untuk wilayah Jakarta sebagian besar cenderung underestimate dibanding data GSMaP, terutama pada bagian Jakarta bagian selatan untuk model (a), (b), (c) dan (d) tetapi berbeda luasan jika dilihat dari intensitasnya. Secara keseluruhan luasan terbesar dengan nilai yang mendekati curah hujan GSMaP diurutkan dari yang terbaik adalah model (d), model (c), model (a) dan model (b).
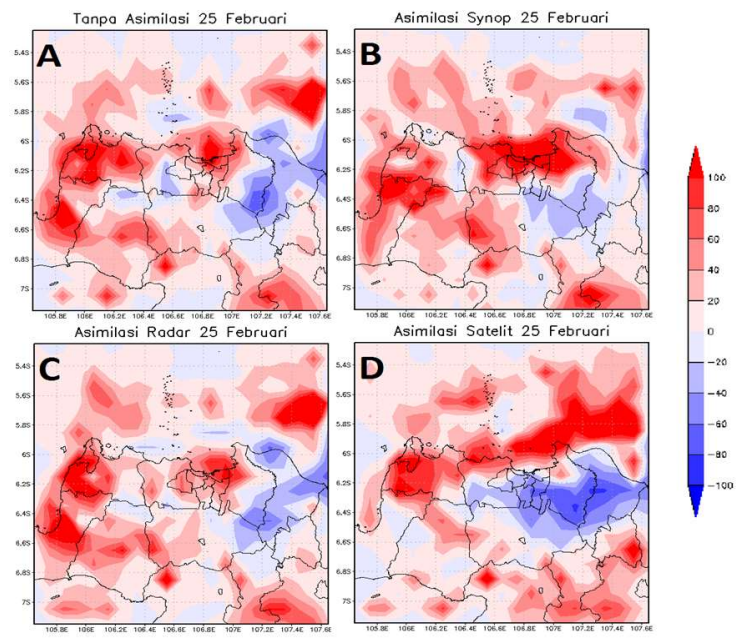

Gambar 3. Selisih curah hujan spasial GSMaP dan model numerik wilayah Jakarta hasil overlay tanggal 25 Februari 2016.

Gambar 3 menunjukkan hasil keluaran model untuk wilayah Jakarta dominannya adalah overestimate untuk model (a), (b) dan (c) khususnya Jakarta bagian utara sedangkan untuk model (d) dominan underestimate terutama Jakarta bagian selatan dan barat. Secara keseluruhan luasan terbesar dengan nilai yang mendekati curah hujan GSMaP tanpa membedakan underestimate maupun overestimate diurutkan dari yang terbaik adalah model (d), model (c), model (a) dan model (b).
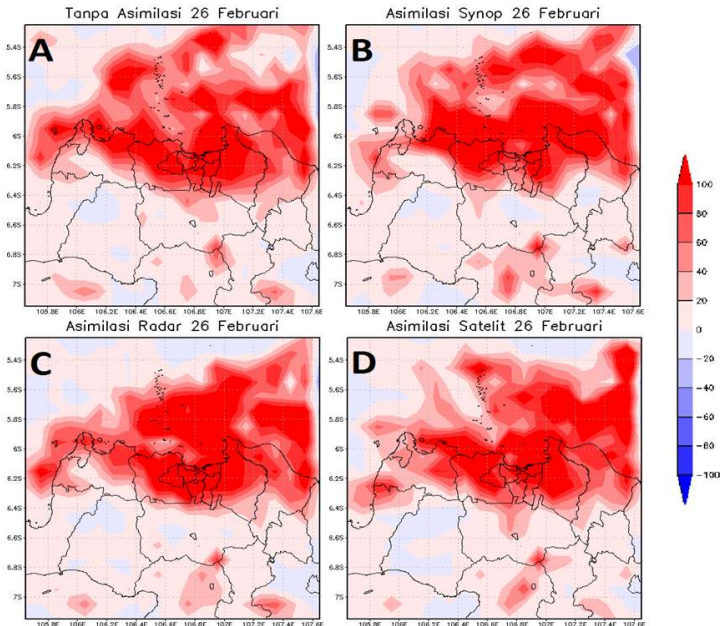

Gambar 4. Selisih curah hujan spasial GSMaP dan model numerik wilayah Jakarta hasil overlay 26 Februari 2016.

Gambar 4 menunjukkan hasil keluaran model untuk wilayah Jakarta dominannya adalah overestimate untuk model (a), (b), (c) dan (d), intensitas terbesar berada di bagian Jakarta sebelah utara. Secara keseluruhan luasan terbesar dengan nilai yang mendekati curah hujan GSMaP diurutkan dari yang terbaik adalah model (b), model (d), model (c) dan model (a).
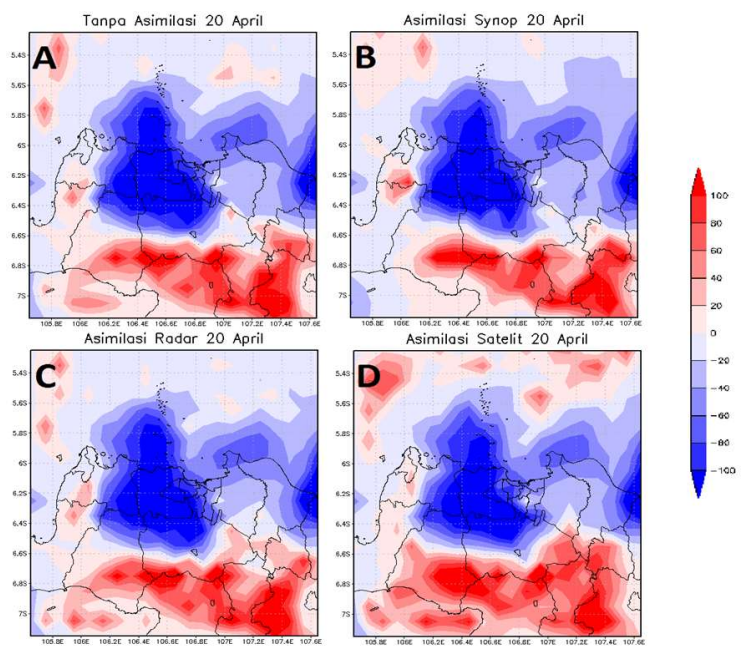

Gambar 5. Selisih curah hujan spasial GSMaP dan model numerik wilayah Jakarta hasil overlay tanggal 20 April 2016.

Gambar 5 menunjukkan hasil keluaran model untuk wilayah Jakarta dominannya adalah underestimate untuk model (a), (b), (c) dan (d), intensitas terbesar berada di bagian Jakarta sebelah utara. Secara keseluruhan luasan 
terbesar dengan nilai yang mendekati curah hujan GSMaP diurutkan dari yang terbaik adalah model (d), model (c), model (b), dan model (a).
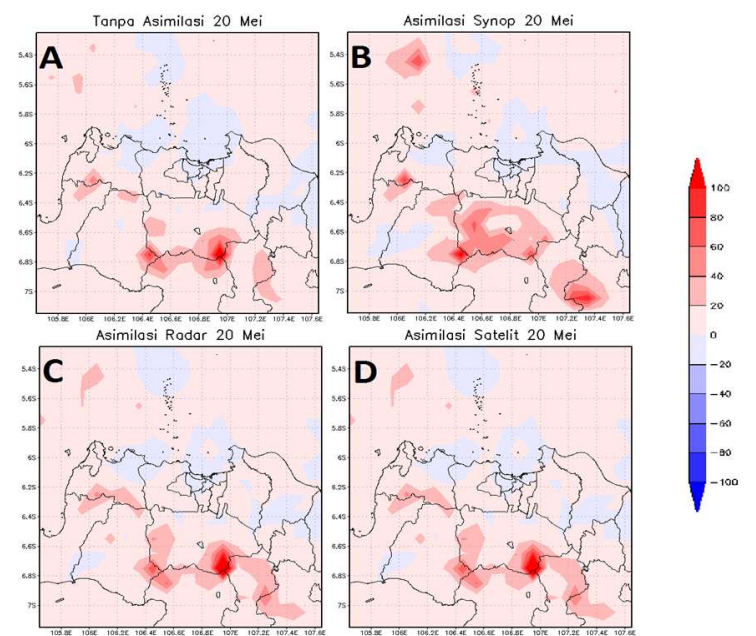

Gambar 6. Selisih curah hujan spasial GSMaP dan model numerik wilayah Jakarta hasil overlay tanggal 20 Mei 2016.

Gambar 6 menunjukkan hasil keluaran model untuk wilayah Jakarta dominannya adalah sangat mendekati dengan data curah hujan GSMaP untuk model (a), (b), (c) dan (d), maka dapat dikatakan jika ke empat hasil keluaran model pada tanggal 20 Mei 2016 mempunyai performa yang hampir sama baiknya.
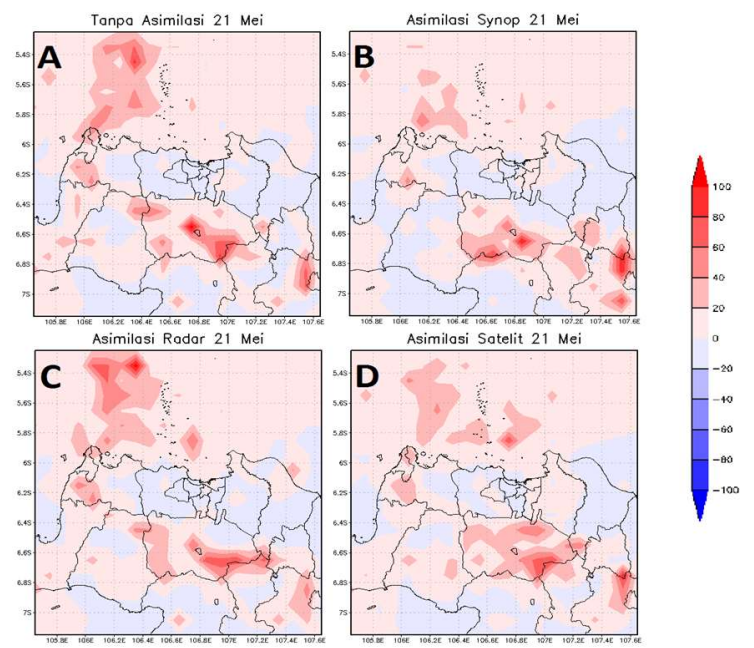

Gambar 7. Selisih Curah hujan Spasial GSMaP dan model numerik wilayah Jakarta hasil overlay tanggal 21 Mei 2016.

Gambar 7 menunjukkan hasil keluaran model untuk wilayah Jakarta dominannya adalah sangat mendekati dengan data curah hujan GSMaP untuk model (a), (b), (c) dan (d), maka dapat dikatakan jika ke empat hasil keluaran model pada tanggal 21 Mei 2016 mempunyai performa yang hampir sama baiknya.
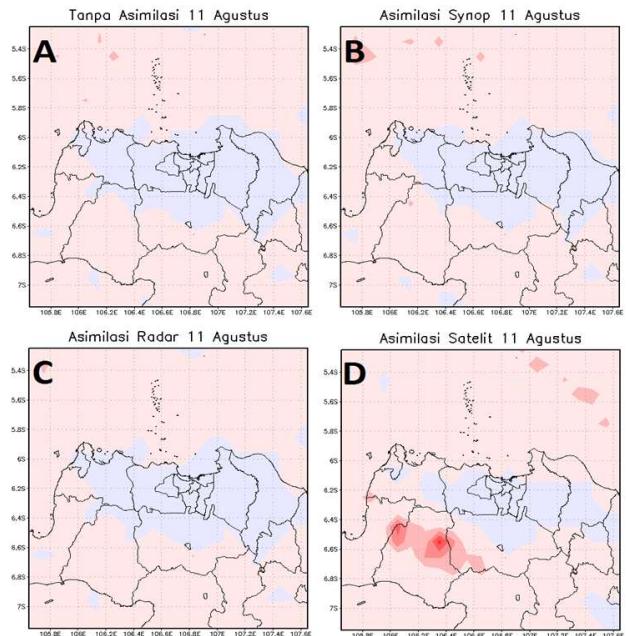

Gambar 8. Selisih curah hujan spasial GSMaP dan model numerik wilayah Jakarta hasil overlay tanggal 11 Agustus 2016.

Gambar 8 menunjukkan hasil keluaran model untuk wilayah Jakarta dominannya adalah sangat mendekati dengan data curah hujan GSMaP untuk model (a), (b), (c) dan (d) walaupun cenderung seluruhnya underestimate untuk wilayah Jakarta, maka dapat dikatakan jika ke empat hasil keluaran model pada tanggal 11 Agustus 2016 mempunyai performa yang hampir sama baiknya.

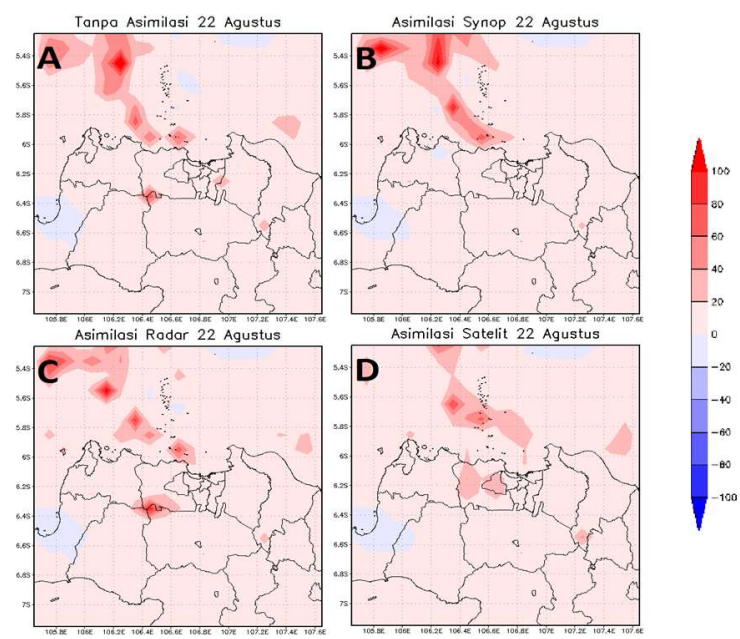

Gambar 9. Selisih curah hujan spasial GSMaP dan model numerik wilayah Jakarta hasil overlay tanggal 22 Agustus 2016.

Gambar 9 menunjukkan hasil keluaran model untuk wilayah Jakarta dominannya adalah sangat mendekati dengan data curah hujan GSMaP untuk model (a), (b), (c) dan (d) walaupun cenderung seluruhnya overestimate untuk wilayah Jakarta, maka dapat dikatakan jika hasil keluaran model (b) dan (c) pada tanggal 22 Agustus 2016 mempunyai performa yang sedikit lebih baik daripada model (a) dan (d). 
Gambar 10 menunjukkan hasil keluaran model untuk wilayah Jakarta dominannya adalah sangat mendekati dengan data curah hujan GSMaP untuk model (a), (b), dan (c) walaupun cenderung seluruhnya underestimate untuk wilayah Jakarta, sedangkan model (d) cenderung overestimate, maka dapat dikatakan jika keempat hasil keluaran model pada tanggal 23 Agustus 2016 mempunyai performa yang hampir sama baiknya.

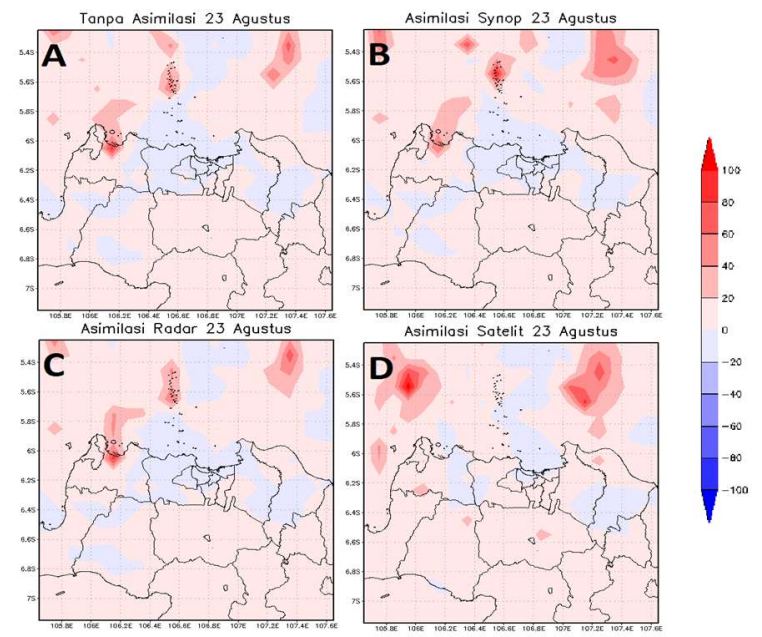

Gambar 10. Selisih curah hujan spasial GSMaP dan model numerik wilayah Jakarta hasil overlay tanggal 23 Agustus 2016.

Gambar 11 menunjukkan hasil keluaran model untuk wilayah Jakarta dominannya adalah underestimate untuk model (a), (b), (c) dan (d), intensitas terbesar berada di bagian Jakarta sebelah utara. Secara keseluruhan luasan terbesar dengan nilai yang mendekati curah hujan GSMaP diurutkan dari yang terbaik adalah model (c), model (a), model (d) dan model (b).

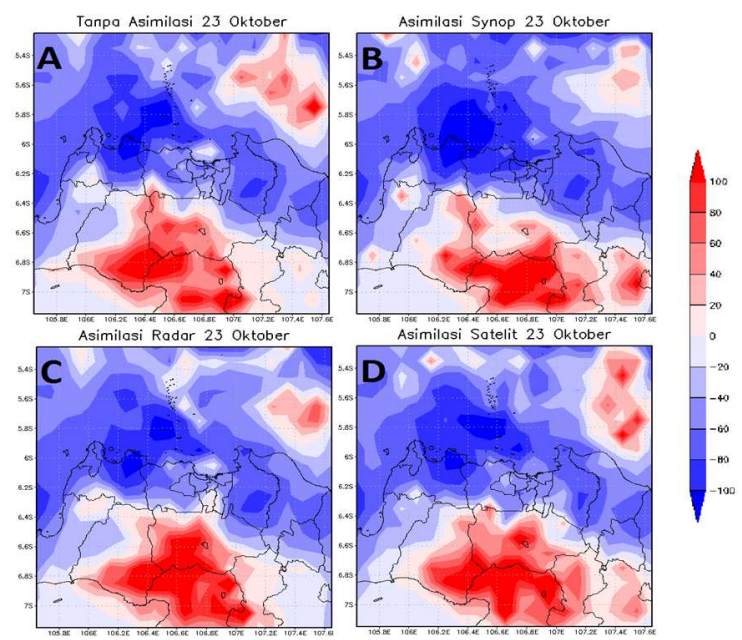

Gambar 11. Selisih curah hujan spasial GSMaP dan model numerik wilayah Jakarta hasil overlay tanggal 23 Oktober 2016.

Gambar 12 menunjukkan hasil keluaran model untuk wilayah Jakarta dominannya adalah sangat mendekati data curah hujan GSMaP untuk model (a), (b), dan (c) walaupun cenderung seluruhnya underestimate untuk wilayah Jakarta, sedangkan model (d) cenderung overestimate di daerah Jakarta Selatan, maka dapat dikatakan jika ke empat hasil keluaran model pada tanggal 25 Oktober 2016 mempunyai performa yang hampir sama baiknya untuk model (a), (b), dan (c), sedangkan model (d) performanya sedikit lebih rendah daripada ketiga model lainnya.
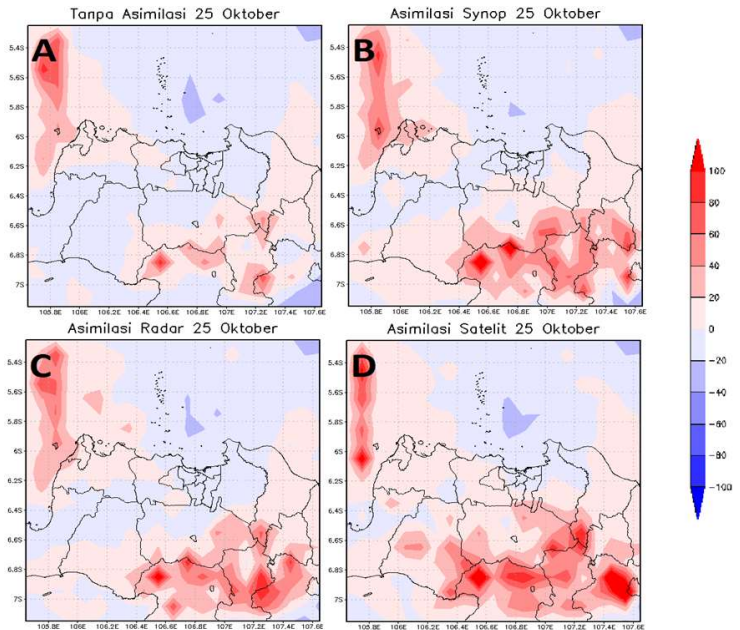

Gambar 12. Selisih curah hujan spasial GSMaP dan model numerik wilayah Jakarta hasil overlay tanggal 25 Oktober 2016.

Hasil dari keseluruhan dapat kita ketahui jika data curah hujan hasil keluaran model dengan asimilasi satelit hampir mendekati data curah hujan GSMaP, tapi punya kecenderungan underestimate. Hasil keluaran model dengan asimilasi radar adalah yang terbaik kedua dengan pola kecenderungan underestimate dan overestimate hampir sama dengan model dengan asimilasi data sinoptik dan tanpa asimilasi. Terbaik ketiga adalah model dengan asimilasi data sinoptik dengan hasil yang sedikit lebih baik daripada model tanpa asimilasi data. Analisis per wilayah menunjukkan jika data curah hujan secara keseluruhan di wilayah Jakarta Selatan punya peluang underestimate tertinggi, sebaliknya wilayah Jakarta Utara hasil prediksinya lebih sering overestimate. Wilayah Jakarta Timur mempunyai hasil prediksi yang lebih baik ketimbang wilayah Jakarta lainnya.

\section{KESIMPULAN}

Dari penelitian yang dijalankan dengan membandingkan hasil model WRF tanpa asimilasi dan dengan asimilasi data sinoptik, asimilasi data radar, dan asimilasi data satelit pada kasus 11 hari yang diangkat pada penelitian ini di wilayah Jakarta, menghasilkan kesimpulan bahwa pada uji performa model melalui tabel kontingensi untuk nilai PC, TS, FAR, dan POD, Model asimilasi data satelit (AMSU-A dan MHS) menunjukkan adanya 
perbaikan performa yang paling baik untuk kriteria prediksi hujan secara dikotomi hujan/tidak hujan dengan nilai akurasi 0.81 , selanjutnya asimilasi data sinoptik dengan nilai akurasi 0.78 kemudian asimilasi data radar (reflektivitas) dengan nilai akurasi 0.77 .

Pada kriteria hujan ringan, performa model dengan asimilasi data satelit merupakan yang paling baik dengan nilai prediksi tepat (HIT) sebesar 0.80. Untuk kriteria hujan sangat lebat model dengan asimilasi data sinoptik memberikan hasil yang paling baik dengan nilai prediksi tepat sebesar 0.50 , sedangkan untuk kriteria hujan sedang dan lebat, model tanpa asimilasi masih memberikan hasil yang paling baik diantara keempat model lainnya.

Pada hasil spasial, seluruh model dengan asimilasi data memberikan perbaikan performa dibandingkan dengan model tanpa asimilasi data. Model dengan asimilasi data satelit memberikan hasil yang paling mendekati data curah hujan GSMaP kemudian selanjutnya adalah model asimilasi data radar dan terakhir model asimilasi data sinoptik.

\section{DAFTAR PUSTAKA}

Auligne, T., et al. (2009). Satellite Data Assimilation in WRF-Var. UCAR.

Dash, S.K., Sahu, D.K., Sahu, S.C. (2013). Impact of AWS Observation in WRF-DVAR Data Assimilation System: a Case Study on Abnormal Warming Condition in Odisha. Nethazard, 65, 767-798.

Gustari, I. (2014). Perbaikan Prediksi Cuaca Numerik Kejadian Hujan Sangat Lebat Terkait dengan Sistem Awan di Jabodetabek Menggunakan Asimilasi Data Radar C-Band. Disertasi. Institut Teknologi Bandung.

Gustari, I., Hadi, T.W., Hadi, S., Renggono, F. (2012). Akurasi Prediksi Curah Hujan Harian Operasional di Jabodetabek: Perbandingan dengan Model WRF. Jurnal Meteorologi dan Geofisika, Vol.13(2), 119130.

Hadi, T.W., et al. (2011). Pelatihan Model WRF (Weather Research and Forecasting). Laboratorium Analisis Meteorologi (Weather and Research Prediction Laboratory) Fakultas IImu dan Teknologi Kebumian ITB, Bandung.

Harper, K., Uccellini, L.W., Kalnay, E., Carey, K., Morone, L. (2007). 50th Anniversary of Operational Numerical Weather Prediction. Bulletin of American Meteorological Society 88(5), 639-650. doi: 10.1175/BAMS-88-5639

Holton, J.R. (2004). An Introduction to Dynamic Meteorology Third Edition. California: Academis Press Inc. San Diego, California: Elsevier Academic Press.
Kalnay, E. (2003). Atmospheric Modelling, Data Assimilation and Predictability. Cambridge, UK: Cambridge University Press.

National Centers for Environmental Prediction/National Weather Service/NOAA/U.S. Department of Commerce, 2015: NCEP GFS 0.25 Degree Global Forecast Grids Historical Archive. Research Data Archive at the National Center for Atmospheric Research, Computational and Information Systems Laboratory, Boulder, CO. [Available online at https://doi.org/10.5065/D65D8PWK.]

National Centers for Environmental Prediction/National Weather Service/NOAA/U.S. Department of Commerce, 2004: NCEP ADP Global Surface Observational Weather Data, October 1999 - continuing. Research Data Archive at the National Center for Atmospheric Research, Computational and Information Systems Laboratory, Boulder, CO. [Available online at http://rda.ucar.edu/datasets/ds461.0/.]

National Centers for Environmental Prediction/National Weather Service/NOAA/U.S. Department of Commerce, 2009: NCEP GDAS Satellite Data 2004-continuing. Research Data Archive at the National Center for Atmospheric Research, Computational and Information Systems Laboratory, Boulder, CO. [Available online at http://rda.ucar.edu/datasets/ds735.0/.]

Paski, J.A.I., Permana, Y.H., Pertiwi, D.A.S. (2017). Analisis Sebaran Petir Cloud to Ground (CG) di Wilayah Jabodetabek pada Tahun 2016. Prosiding Seminar Nasional Fisika (E-Journal SNF 2017) Vol. 6. EPA, 65-72.

Paski, J.A.I. (2017). Pengaruh Asimilasi Data Radar C-Band dalam Prediksi Cuaca Numerik (Studi Kasus di Lampung). Jurnal Meteorologi dan Geofisika, Vol.18(2), 5564.

Paski, J.A.I. (2017). Pengaruh Asimilasi Data Penginderaan Jauh (Radar dan Satelit) pada Prediksi Cuaca Numerik Untuk Estimasi Curah Hujan. Jurnal Penginderaan Jauh dan Pengolahan Data Citra Digital, Vol.14(2), 79-88.

Sahu, D.K., Dash, S.K., Bhan, S.C. (2014). Impact of Surface Observations on Simulation of Rainfall over NCR Delhi Using Regional Background Error Statistic in WRF-3DVAR Model. Meterology and Atmospheric Physics, Vol.125(1-2), 17-42.

Satrya, L.I. (2012). Asimilasi Data Radar dalam Penerapan Prediksi Cuaca Numerik di Indonesia (Studi Kasus di Jawa Barat). Meteorologi ITB: Bandung. 
Sun, J., Crook, N.A. (1997). Dynamical and Microphysical Retrieval from Doppler Radar Observations Using a Cloud Model and Its Adjoint. Part I: Model Development and Simulated Data Experiments. Journal of the Atmospheric Sciences, Vol.54(12), 16421661 doi: 10.1175/15200469(1997)054<1642:DAMRFD>2.0.CO;2

Sun, J., Wang, H. (2013). Radar Data Assimilation with WRF 4D-Var. Part II: Comparison with 3D-Var for a Squall Line over the U.S. Great Plains. Monthly Weather Review, 141(7), 2245-2264. doi: 10.1175/MWR-D-1200169.1 .
Talagrand, O. (1997). Assimilation of Observation, an Introduction (gtSpecial IssueltData Assimilation in Meteorology and Oceanography: Theory and Practice). Journal of the Meteorological Society of Japan, Vol.75(1B), 191-209. doi: 10.2151/jmsj1965.75.1B_191.

Yang, J., Duan, K., Wu, J., Qin, X., Shi, P., Liu, H., Xie, X., Zhang, X., Sun, J. (2015). Effect of Data Assimilation Using WRF-3DVAR for Heavy Rain Prediction on the Northeastern Edge of the Tibetan Plateau. Hindawi: Advances in Meteorology Volume 2015. doi: 10.1155/2015/294589. 